Jurnal Algoritme

Vol. 1, No. 1, Oktober 2020, Hal. 1 - 11

\title{
Klasifikasi American Sign Language Menggunakan Fitur Scale Invariant Feature Transform dan Jaringan Saraf Tiruan
}

\author{
M. Restu Alviando*1, M. Ezar Al Rivan ${ }^{2}$, Yoannita $^{3}$ \\ STMIK GI MDP, Jalan Rajawali No.14 Palembang, 0711-376400 \\ Program Studi Teknik Informatika, STMIK GI MDP Palembang \\ e-mail: *11restualviando@mhs.mdp.ac.id, ${ }^{2}$ meedzhar@mdp.ac.id, ${ }^{3}$ yoannita@mdp.ac.id
}

\begin{abstract}
Abstrak
American Sign Language (ASL) merupakan salah satu jenis bahasa isyarat yang ada didunia. Penelitian ini menggunakan metode Jaringan Saraf Tiruan (JST) sebagai klasifikasi dan fitur Scale Invariant Feature Transform (SIFT) sebagai ekstraksi citra ASL. Data latih dan data uji untuk citra ASL diekstraksi menggunakan fitur SIFT kemudian dilakukan pelatihan JST dengan menggunakan 17 training function dengan 2 hidden layer. Jumlah neuron yang dilakukan adalah [250-5-10-24], [250-5-15-24] dan [250-15-15-24] sehingga terdapat 3 arsitektur JST yang berbeda. Tiap arsitektur dilakukan sebanyak 3 kali sehingga terdapat 9 percobaan (3 arsitektur $x 3$ percobaan run program). Penentuan jumlah neuron yang disimpulkan pada training function dipilih hasil terbaik pengujian pada data uji. Berdasarkan training function dan hasil ekstraksi fitur SIFT sebagai nilai input pada jaringan saraf tiruan dapat disimpulkan bahwa dari 17 training function, trainb dengan arsitektur neuron [250-5-10-24] menjadi training function terbaik menghasilkan nilai akurasi sebesar 95\%, precision sebesar 15\% dan recall sebesar $5 \%$.
\end{abstract}

Kata kunci-SIFT, JST, ASL.

\begin{abstract}
American Sign Language (ASL) is a sign language in the world. This study uses the neural network method as a classification and the scale invariant feature transform (SIFT) as feature extraction. Training data and test data for ASL images were extracted using the SIFT feature, then ANN training was conducted using 17 training functions with 2 hidden layers. There are architecture used [250-5-10-24], [250-5-15-24] and [250-15-15-24] so there are 3 different ANN architectures. Each architecture is performed 3 times so that there are 9 experiments $(3 x$ 3 trials run the program). Determination of the number of neurons concluded by the training function is selected by the best test results on the test data. Based on the training function and the extraction of SIFT features as input values in the neural network it can be concluded that from 17 training functions, trainb with neuron architecture [250-5-10-24] becomes the best training function producing an accuracy value of $95 \%$, precision of $15 \%$ and recall $5 \%$.
\end{abstract}

Keywords - SIFT, Neural Network, ASL. 


\section{PENDAHULUAN}

$\mathrm{B}$ ahasa isyarat merupakan salah satu media komunikasi bagi para tuna rungu dan tuna wicara dalam berkomunikasi ke satu sama lain ataupun ke masyarakat umum. Bahasa isyarat sangat berguna untuk berkomunikasi dalam kehidupan sehari-hari karena sistem ini dapat menjadikan lawan bicara memahami apa yang disampaikan dengan mengenali pola alfabet yang dibentuk dengan jari sebagai isyarat dalam menyusun kata. Akan tetapi tidak semua masyarakat umum memiliki kemampuan untuk mengerti dalam berkomunikasi dengan bahasa isyarat yang mengakibatkan keterbatasan tuna rungu dan tuna wicara dalam berkomunikasi dengan masyarakat [1]. Masalah tersebut dapat diatasi dengan suatu sistem yang dapat mengenali pola alfabet dalam bahasa isyarat sehingga dapat membantu masyarakat umum dalam berkomunikasi dengan bahasa isyarat. Setiap negara bahkan daerah masing - masing memiliki bahasa isyarat yang berbeda - beda salah satunya adalah American Sign Language (ASL). ASL adalah bahasa isyarat yang bersifat linguistik yang sama dengan bahasa lisan yang diekspresikan dengan gerakan tangan. ASL banyak digunakan tuna rungu di Amerika utara sebagai bahasa utama dalam berkomunikasi [2].

Terdapat beberapa penelitian terdahulu yang melakukan pengenalan alfabet ASL, yaitu penelitian yang dilakukan [3] yang juga berhasil melakukan penelitian tentang pengenalan alfabet bahasa isyarat Amerika menggunakan Edge Oriented Histogram dan Image Matching yang menghasilkan kesimpulan bahwa fitur 9 bin dan metode Sum of Absolute Difference menjadi pilihan dalam pengenalan ASL. Penelitian juga pernah dilakukan oleh [4] yang berhasil melakukan pengenalan alfabet ASL menggunakan fitur Histogram of Oriented Fradient (HOG) sebagai ekstraksi citra dan untuk klasifikasi menggunakan $k$-Nearest Neighbors (k-NN) yang menghasilkan bahwa hasil uji terbaik adalah 0.99 dengan menggunakan Euclidean Distance dan Manhattan Distance ketika nilai k=3 dan k=5.

Terdapat beberapa metode yang dapat digunakan untuk mengklasifikasikan objek, salah satunya yaitu JST (Jaringan Saraf Tiruan) yang digunakan dalam penelitian [5] yang berhasil melakukan identifikasi potensi glaukoma dan retinopati diabetes melalui citra fundus dengan menggunakan JST yang menghasilkan rata-rata untuk recall sebesar 86,6\%, precission sebesar $86,6 \%$, dan untuk accuracy sebesar $91,06 \%$. Pada penelitian yang lain yang dilakukan [6] berhasil melakukan klasifikasi jenis kacang pada kacang merah, kacang hijau dan kacang tanah. Penelitian tersebut menggunakan fitur Grey Level Co-occurence Matrix (GLCM) sebagai ekstraksi citra dan JST sebagai klasifikasi yang menghasilkan akurasi sebesar 99,8\%, presisi sebesar 99,6\% dan recal sebesar 99,8\%.

Dalam melakukan klasifikasi terdapat beberapa fitur untuk mendapatkan informasi dari citra, salah satunya fitur Scale Invariant Feature Transform (SIFT) yang terdapat dalam penelitian yang telah dilakukan [7] dengan judul Indonesian Sign Language Number Recognition using SIFT Algorithm. Penelitian ini menghasilkan nilai akurasi sebesar $82 \%$ dengan total 100 contoh gambar dataset yang terbagi 50 contoh gambar untuk data latih dan 50 contoh gambar untuk data uji, sedangkan untuk threshold terbaik di angka 0.45 dapat menghasilkan nilai akurasi sebesar 94\%. Penelitian yang terkait dengan SIFT juga pernah dilakukan [8] berhasil melakukan penelitian Implementation of Indian Sign Language Recognition System using SIFT dengan hasil akurasi 98,7\%. Penelitian lainnya yang juga pernah dilakukan [9] yang berhasil melakukan penelitian Hand Gesture Recognition using SIFT Features on Depth Image yang menghasilkan nilai akurasi sebesar $99 \%$.

Berdasarkan penelitian - penelitian yang telah diuraikan di atas, menunjukkan bahwa fitur klasifikasi SIFT mampu mengenali objek dengan akurasi 94\%. Namun belum pernah dilakukan penelitian menggunakan JST sebagai klasifikasi dan fitur SIFT sebagai ekstraksi. Berdasarkan hal tersebut maka penelitian ini dilakukan untuk mengetahui tingkat akurasinya.

Alviando, at., al (Klasifikasi American Sign Language Menggunakan Fitur Scale Invariant Feature Transform Dan Jaringan Saraf Tiruan) 


\section{METODE PENELITIAN}

Berikut adalah beberapa tahapan yang dilakukan dapat dilihat pada Gambar 1 untuk mengklasifikasi ASL menggunakan fitur SIFT dan JST.

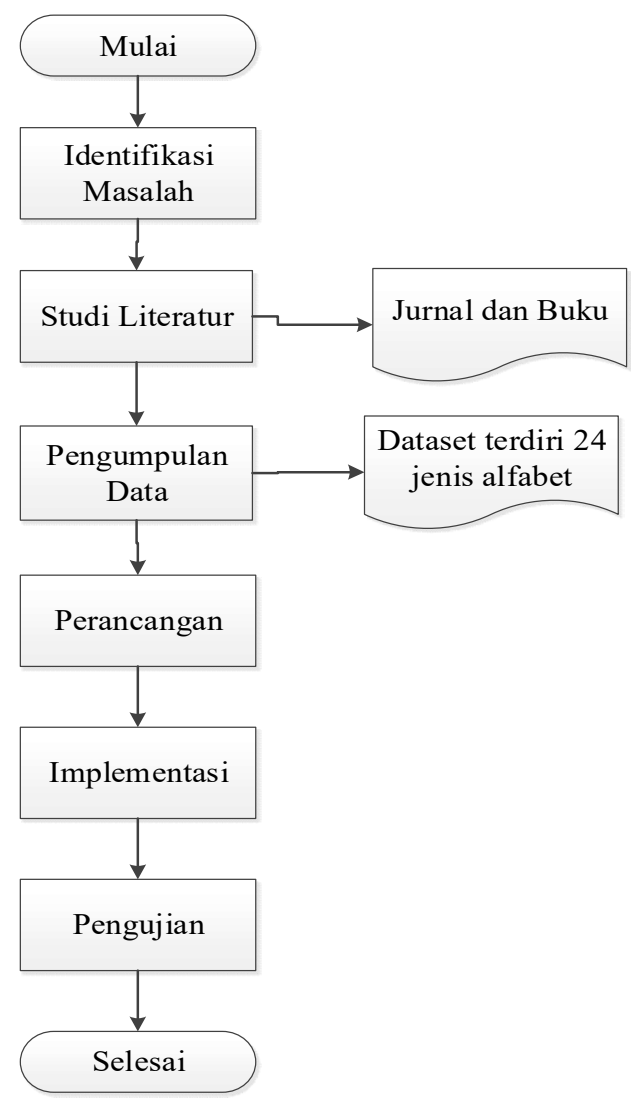

Gambar 1 Kerangka Kerja Penelitian

\section{Identifikasi Masalah}

Pada tahapan ini, penelitian melakukan identifikasi masalah penelitian yang berkaitan dengan citra bahasa isyarat dan pengenalan pola fingerspelling dari alfabet ASL. Alfabet yang digunakan terdiri dari 24 huruf yaitu huruf A sampai Z, kecuali J dan Z karena kedua huruf ini merupakan huruf dinamis yang membutuhkan pergerakan jari.

\section{Studi Literatur}

Tahapan ini melakukan pencarian beberapa jurnal yang berkaitan dengan pengenalan bahasa isyarat menggunakan beberapa metode, jurnal yang terkait mengenai metode fitur bentuk SIFT dan metode klasifikasi JST Backpropagation.

\section{Pengumpulan Data}

Pada tahap ini pengumpulan data dilakukan menggunakan dataset dengan total berjumlah 1680 yang terdiri dari 49 citra untuk data latih dan 21 citra untuk data uji untuk setiap alfabet. Citra yang digunakan memiliki resolusi 320 x 240 piksel. Dataset yang digunakan bersifat

Alviando, at., al (Klasifikasi American Sign Language Menggunakan Fitur Scale Invariant Feature Transform Dan Jaringan Saraf Tiruan) 
public yang dapat diambil dari [10] dan untuk jumlah data setiap alfabet dapat dilihat pada Tabel 1.

Tabel 1 Jumlah Data Setiap Jenis Alfabet

\begin{tabular}{|c|c|c|c|c|}
\hline No. & Jenis Alfabet & $\begin{array}{c}\text { Jumlah data yang } \\
\text { dipilih }\end{array}$ & $\begin{array}{c}\text { Jumlah data } \\
\text { training }\end{array}$ & $\begin{array}{c}\text { Jumlah data } \\
\text { testing }\end{array}$ \\
\hline 1. & A & 70 Gambar & 49 Gambar & 21 Gambar \\
\hline 2. & $\mathrm{~B}$ & 70 Gambar & 49 Gambar & 21 Gambar \\
\hline 3. & $\mathrm{C}$ & 70 Gambar & 49 Gambar & 21 Gambar \\
\hline 4. & $\mathrm{D}$ & 70 Gambar & 49 Gambar & 21 Gambar \\
\hline 5. & $E$ & 70 Gambar & 49 Gambar & 21 Gambar \\
\hline 6. & $\mathrm{~F}$ & 70 Gambar & 49 Gambar & 21 Gambar \\
\hline 7. & G & 70 Gambar & 49 Gambar & 21 Gambar \\
\hline 8. & $\mathrm{H}$ & 70 Gambar & 49 Gambar & 21 Gambar \\
\hline 9. & I & 70 Gambar & 49 Gambar & 21 Gambar \\
\hline 10. & $\mathrm{~K}$ & 70 Gambar & 49 Gambar & 21 Gambar \\
\hline 11. & $\mathrm{~L}$ & 70 Gambar & 49 Gambar & 21 Gambar \\
\hline 12. & $\mathrm{M}$ & 70 Gambar & 49 Gambar & 21 Gambar \\
\hline 13. & $\mathrm{~N}$ & 70 Gambar & 49 Gambar & 21 Gambar \\
\hline 14. & $\mathrm{O}$ & 70 Gambar & 49 Gambar & 21 Gambar \\
\hline 15. & $\mathrm{P}$ & 70 Gambar & 49 Gambar & 21 Gambar \\
\hline 16. & $\mathrm{Q}$ & 70 Gambar & 49 Gambar & 21 Gambar \\
\hline 17. & $\mathrm{R}$ & 70 Gambar & 49 Gambar & 21 Gambar \\
\hline 18. & $\mathrm{~S}$ & 70 Gambar & 49 Gambar & 21 Gambar \\
\hline 19. & $\mathrm{~T}$ & 70 Gambar & 49 Gambar & 21 Gambar \\
\hline 20. & $\mathrm{U}$ & 70 Gambar & 49 Gambar & 21 Gambar \\
\hline 21. & $\mathrm{~V}$ & 70 Gambar & 49 Gambar & 21 Gambar \\
\hline 22. & $\mathrm{~W}$ & 70 Gambar & 49 Gambar & 21 Gambar \\
\hline 23. & $\mathrm{X}$ & 70 Gambar & 49 Gambar & 21 Gambar \\
\hline 24. & $\mathrm{Y}$ & 70 Gambar & 49 Gambar & 21 Gambar \\
\hline \multicolumn{2}{|c|}{ Total } & 1.680 Gambar & 1.176 Gambar & 504 Gambar \\
\hline
\end{tabular}

\section{Data Training}

Data Training atau data latih merupakan data yang sudah ada sebelumnya (dataset) berupa huruf A sampai Y (kecuali J dan Z) yang berjumlah 49 citra untuk masing-masing huruf yang akan digunakan untuk melatih algoritma.

\section{Data Testing}

Data Testing atau data uji merupakan data yang digunakan untuk mengetahui keakuratan atau performa dari algoritma yang sudah dilatih sebelumnya ketika menemukan data baru.

Alviando, at., al (Klasifikasi American Sign Language Menggunakan Fitur Scale Invariant Feature Transform Dan Jaringan Saraf Tiruan) 
Vol. 1, No. 1, Oktober 2020, Hal. 1 - 11

\section{Perancangan}

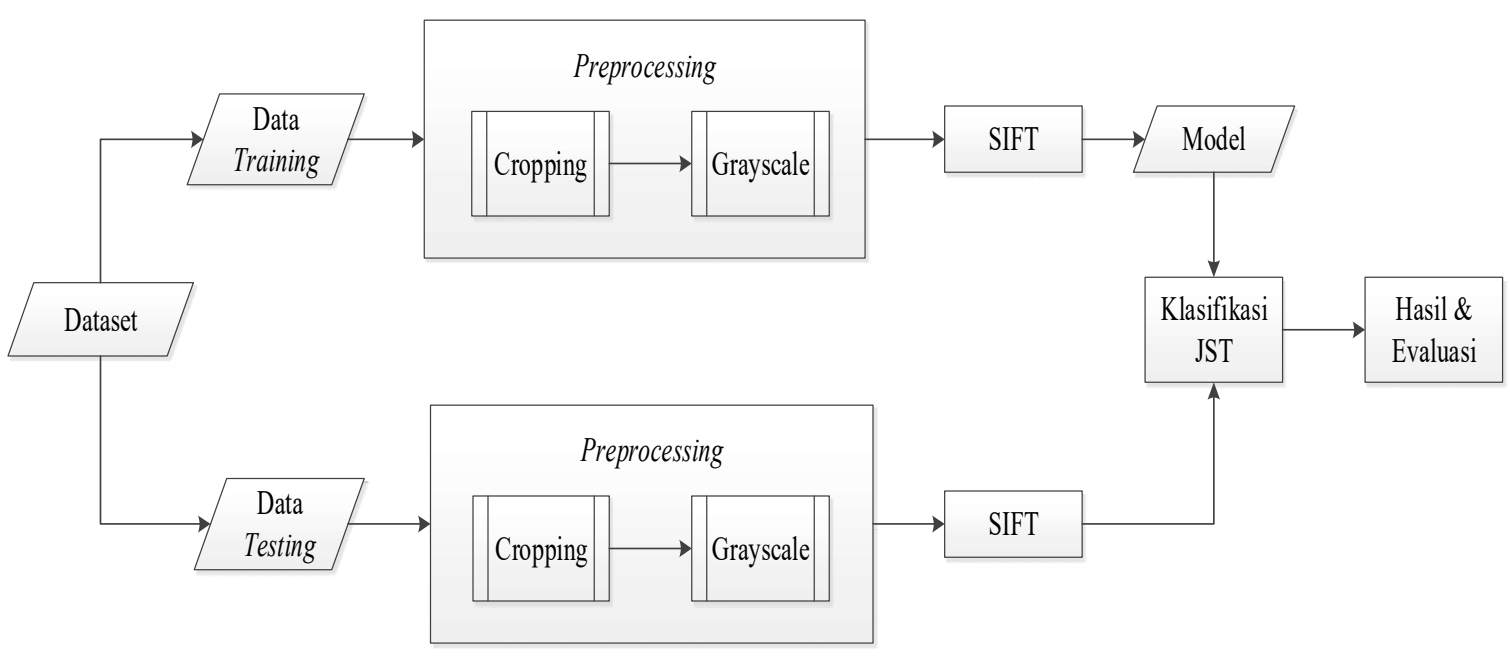

Gambar 2 Perancangan

Berdasarkan gambar 2 pada tahapan perancangan ini peneliti melakukan perancangan skema penelitian. Untuk fase training mula - mula citra melalui preprocessing yaitu citra di cropping lalu di ekstraksi menggunakan fitur SIFT. Selanjutnya data di training menggunakan JST dengan inputan neuron dari hasil ekstraksi SIFT yang sudah dikonversi ke bentuk biner sehingga didapatkan bentuk model JST. Untuk fase testing mula - mula citra melalui preprocessing yaitu citra di cropping lalu di ekstraksi menggunakan fitur SIFT. Selanjutnya citra diklasifikasi menggunakan JST dengan inputan neuron dari hasil ekstraksi SIFT yang sudah dikonversi ke bentuk biner berdasarkan model JST yang sudah ada. Proses terakhir perhitungan hasil berupa accuracy, precision dan recall.

\section{Implementasi}

Setelah proses perancangan dilakukan, pada tahapan ini dilakukan implementasi terhadap rancagan yang telah dibuat kedalam program matlab.

\section{Pengujian}

Setelah dilakukan proses implementasi dilanjutkan dengan proses pengujian pada citra training dan citra testing dari setiap alfabet untuk mengetahui seberapa besar tingkat keberhasilan akurasi yang didapatkan. Pengujian dilakukan dengan menggunakan metode JST Backpropagation sebagai metode untuk klasifikasi dataset yang sudah diekstraksi dengan fitur SIFT. Selanjutnya dilakukan evaluasi terhadap hasil dari klasifikasi berupa accuracy, precision dan recall dengan menggunakan Confusion Matrix yang dapat dilihat pada Tabel 2.

Tabel 2 Confusion Matrix

\begin{tabular}{|c|c|c|c|}
\hline & \multicolumn{2}{|c|}{ True Values } \\
\hline & & True & False \\
\hline \multirow{2}{*}{ 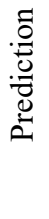 } & $\underset{E}{\stackrel{E}{E}}$ & $\begin{array}{c}\text { TP } \\
\text { Correct Result }\end{array}$ & $\begin{array}{c}\text { FP } \\
\text { Unexpected Result }\end{array}$ \\
\hline & $\begin{array}{l}\mathscr{\mathscr { D }} \\
\frac{\pi}{\pi} \\
\text { [I }\end{array}$ & $\begin{array}{l}\text { FN Missing } \\
\text { Result }\end{array}$ & $\begin{array}{c}\text { TN } \\
\text { Correct absence of } \\
\text { Result }\end{array}$ \\
\hline
\end{tabular}

Alviando, at., al (Klasifikasi American Sign Language Menggunakan Fitur Scale Invariant Feature Transform Dan Jaringan Saraf Tiruan) 


$$
\begin{aligned}
& \text { Presision }=\frac{T P}{T P+F} \\
& \text { Recall }=\frac{T P}{T P+F N} \\
& \text { Accuracy }=\frac{T P+T}{T P+T N+F P+F N} \\
& \text { Overall Accuracy }=\frac{\sum \text { Data Uji Benar }}{\sum \text { Total Uji }} \times 100 \%
\end{aligned}
$$

Keterangan :

$\mathrm{TP}=$ Jumlah data positif citra yang terklasifikasi dengan benar oleh sistem.

$\mathrm{TN}=$ Jumlah data negatif citra yang terklasifikasi dengan benar oleh sistem.

$\mathrm{FN}=$ Jumlah data negatif citra yang terklasifikasi salah oleh sistem.

$\mathrm{FP}=$ Jumlah data positif citra yang terklasifikasi salah oleh sistem.

\section{HASIL DAN PEMBAHASAN}

Pengujian dilakukan dengan menggunakan 24 jenis alfabet menggunakan dataset dengan total berjumlah 1680 yang terdiri dari 49 citra untuk data latih dan 21 citra untuk data uji untuk setiap alfabet. Penelitian ini meliputi tahap ektraksi fitur SIFT dan implementasi model jaringan saraf tiruan.

\subsection{Implementasi Ekstraksi Fitur SIFT}

Pada proses implementasi ekstraksi fitur SIFT ini dilakukan pada semua data latih dan data uji. Untuk hasil ekstraksi fitur SIFT pada data latih disimpan dengan nama "features_train" dan hasil ekstraksi fitur SIFT pada data uji disimpan dengan nama "features_test". Ekstraksi fitur SIFT memiliki 4 tahapan yaitu Scale Space Extrama Detection dengan beberapa proses seperti konstruksi DoG Pyramid, lalu mendeteksi ekstrema pada skala dan oktav, dan komputasi stable keypoint. Setelah keypoint ditemukan tahapan selanjutnya adalah Keypoint Localization yaitu pengambilan detail kandidat keypoint berupa lokasi, skala dan rasio kelengkungan. Setelah pengambilan detail kandidat keypoint dilakukan, tahapan selanjutnya adalah Orientation Assigment untuk mentapkan orientasi pada keypoint. Tahapan yang terakhir adalah keypoint Descriptor yaitu pemberian deskripsi komputasi pada setiap keypoint berdasarkan lokasi, skala dan orientasi yang sudah dihitung.

\subsection{Implementasi Model Jaringan Syaraf Tiruan}

Pada tahap implementasi model jaringan syaraf tiruan menggunakan train tool pada aplikasi MATLAB R2019a terhadap hasil ekstraksi SIFT yang disimpan dengan nama "Features_train" sehingga JST mampu untuk mengenali data latih. Kemudian untuk nilai target pada data latih disimpan dengan nama "target_train".

\subsection{Pengujian JST dan Hasil pada Function Training Trainb}

Pengujian JST yang menggunakan function training trainb merupakan hasil dari implementasi JST setelah dilakukan pengujian terhadap data latih dengan 2 hidden layer dan jumlah neuron yang digunakan adalah [250-5-10-24] neuron, [250-5-15-24] neuron, dan [25015-15-24] neuron. Hasil perhitungan tingkat akurasi pengenalan JST terhadap data uji menggunakan confusion matrix dapat dilihat pada Tabel 3.

Alviando, at., al (Klasifikasi American Sign Language Menggunakan Fitur Scale Invariant Feature Transform Dan Jaringan Saraf Tiruan) 
Vol. 1, No. 1, Oktober 2020, Hal. 1 - 11

Tabel 3 Hasil Perhitungan Confusion Matrix pada Function Trainb

\begin{tabular}{|c|c|c|c|c|c|c|c|c|c|}
\hline \multirow{3}{*}{ 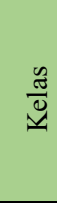 } & \multicolumn{9}{|c|}{ Overall Accuracy } \\
\hline & \multicolumn{3}{|c|}{ Arsitektur [250-5-10-24] } & \multicolumn{3}{|c|}{ Arsitektur [250-5-15-24] } & \multicolumn{3}{|c|}{ Arsitektur [250-15-15-24] } \\
\hline & Accuracy & Precision & Recall & Accuracy & Precisiion & Recall & Accuracy & Precisiion & Recall \\
\hline A & $96 \%$ & $0 \%$ & $0 \%$ & $96 \%$ & $0 \%$ & $0 \%$ & $99 \%$ & $7 \%$ & $10 \%$ \\
\hline $\mathrm{B}$ & $96 \%$ & $0 \%$ & $0 \%$ & $96 \%$ & $0 \%$ & $0 \%$ & $99 \%$ & $0 \%$ & $0 \%$ \\
\hline $\mathrm{C}$ & $70 \%$ & $5 \%$ & $38 \%$ & $96 \%$ & $0 \%$ & $0 \%$ & $95 \%$ & $6 \%$ & $57 \%$ \\
\hline $\mathrm{D}$ & $96 \%$ & $0 \%$ & $0 \%$ & $96 \%$ & $0 \%$ & $0 \%$ & $99 \%$ & $0 \%$ & $0 \%$ \\
\hline E & $96 \%$ & $0 \%$ & $0 \%$ & $96 \%$ & $0 \%$ & $0 \%$ & $99 \%$ & $0 \%$ & $0 \%$ \\
\hline $\mathrm{F}$ & $96 \%$ & $0 \%$ & $0 \%$ & $62 \%$ & $4 \%$ & $38 \%$ & $99 \%$ & $17 \%$ & $5 \%$ \\
\hline G & $96 \%$ & $0 \%$ & $0 \%$ & $96 \%$ & $0 \%$ & $0 \%$ & $99 \%$ & $100 \%$ & $5 \%$ \\
\hline $\mathrm{H}$ & $96 \%$ & $0 \%$ & $0 \%$ & $96 \%$ & $33 \%$ & $5 \%$ & $99 \%$ & $28 \%$ & $24 \%$ \\
\hline I & $96 \%$ & $0 \%$ & $0 \%$ & $88 \%$ & $2 \%$ & $5 \%$ & $99 \%$ & $0 \%$ & $0 \%$ \\
\hline $\mathrm{K}$ & $96 \%$ & $0 \%$ & $0 \%$ & $96 \%$ & $0 \%$ & $0 \%$ & $99 \%$ & $0 \%$ & $0 \%$ \\
\hline $\mathrm{L}$ & $96 \%$ & $0 \%$ & $0 \%$ & $96 \%$ & $0 \%$ & $0 \%$ & $99 \%$ & $0 \%$ & $0 \%$ \\
\hline M & $96 \%$ & $0 \%$ & $0 \%$ & $96 \%$ & $0 \%$ & $0 \%$ & $99 \%$ & $0 \%$ & $0 \%$ \\
\hline $\mathrm{N}$ & $96 \%$ & $0 \%$ & $0 \%$ & $96 \%$ & $0 \%$ & $0 \%$ & $99 \%$ & $7 \%$ & $5 \%$ \\
\hline $\mathrm{O}$ & $96 \%$ & $0 \%$ & $0 \%$ & $87 \%$ & $4 \%$ & $10 \%$ & $97 \%$ & $5 \%$ & $29 \%$ \\
\hline $\mathrm{P}$ & $96 \%$ & $0 \%$ & $0 \%$ & $77 \%$ & $4 \%$ & $19 \%$ & $99 \%$ & $0 \%$ & $0 \%$ \\
\hline Q & $96 \%$ & $0 \%$ & $0 \%$ & $96 \%$ & $0 \%$ & $0 \%$ & $99 \%$ & $0 \%$ & $0 \%$ \\
\hline $\mathrm{R}$ & $96 \%$ & $0 \%$ & $0 \%$ & $96 \%$ & $0 \%$ & $0 \%$ & $99 \%$ & $100 \%$ & $5 \%$ \\
\hline $\mathrm{S}$ & $96 \%$ & $0 \%$ & $0 \%$ & $96 \%$ & $0 \%$ & $0 \%$ & $98 \%$ & $5 \%$ & $10 \%$ \\
\hline $\mathrm{T}$ & $96 \%$ & $0 \%$ & $0 \%$ & $96 \%$ & $0 \%$ & $0 \%$ & $99 \%$ & $0 \%$ & $0 \%$ \\
\hline $\mathrm{U}$ & $96 \%$ & $0 \%$ & $0 \%$ & $96 \%$ & $0 \%$ & $0 \%$ & $99 \%$ & $0 \%$ & $0 \%$ \\
\hline $\mathrm{V}$ & $96 \%$ & $0 \%$ & $0 \%$ & $93 \%$ & $0 \%$ & $0 \%$ & $98 \%$ & $7 \%$ & $14 \%$ \\
\hline $\mathrm{W}$ & $96 \%$ & $0 \%$ & $0 \%$ & $85 \%$ & $9 \%$ & $29 \%$ & $99 \%$ & $0 \%$ & $0 \%$ \\
\hline X & $32 \%$ & $5 \%$ & $81 \%$ & $96 \%$ & $0 \%$ & $0 \%$ & $99 \%$ & $0 \%$ & $0 \%$ \\
\hline $\mathrm{Y}$ & $96 \%$ & $0 \%$ & $0 \%$ & $89 \%$ & $6 \%$ & $10 \%$ & $99 \%$ & $100 \%$ & $99 \%$ \\
\hline
\end{tabular}

Berdasarkan Tabel 3 hasil accuracy untuk arsitektur neuron [250-5-10-24] bernilai 92,51\%, arsitektur neuron [250-5-15-24] bernilai 91,95\% dan arsitektur neuron [250-15-15-24] bernilai 92,26\%. Hasil precision untuk arsitektur neuron [250-5-10-24] bernilai 9,8\%, arsitektur neuron [250-5-15-24] bernilai 1,7\% dan arsitektur neuron [250-15-15-24] bernilai $5,6 \%$. Hasil recall untuk arsitektur neuron [250-5-10-24] bernilai 10\%, arsitektur neuron [2505-15-24] bernilai 3\% dan arsitektur neuron [250-15-15-24] bernilai $7 \%$.

\subsection{Hasil Pengujian JST Menggunakan Function Training}

Pengujian JST yang menggunakan 17 training function dan melakukan pengujian menggunakan hasil dari implementasi JST yang dilakukan terhadap data latih serta arsitektur neuron yang digunakan adalah [250-5-10-24] neuron, [250-5-15-24] neuron dan [250-15-15-24] neuron dapat dilihat pada Tabel 4.

Alviando, at., al (Klasifikasi American Sign Language Menggunakan Fitur Scale Invariant Feature Transform Dan Jaringan Saraf Tiruan) 
Vol. 1, No. 1, Oktober 2020, Hal. 1 - 11

Tabel 4 Hasil Pengujian JST Menggunakan Training Function

\begin{tabular}{|l|l|l|l|l|l|l|l|l|l|l|}
\hline \multirow{2}{*}{ No } & Training & \multicolumn{2}{|c|}{ Aristektur $[250-5-10-24]$} & \multicolumn{3}{|l|}{ Arsitektur $[250-5-15-24]$} & \multicolumn{3}{|c|}{ Arsitektur [250-15-15-24] } \\
\cline { 3 - 11 } & Function & Akurasi & Presisi & Recall & Akurasi & Presisi & Recall & Akurasi & Presisi & Recall \\
\hline 1 & Trainbr & $92 \%$ & $9 \%$ & $9 \%$ & $92 \%$ & $9 \%$ & $9 \%$ & $93 \%$ & $10 \%$ & $10 \%$ \\
\hline 2 & Trainlm & $92 \%$ & $6 \%$ & $6 \%$ & $92 \%$ & $6 \%$ & $7 \%$ & $93 \%$ & $9 \%$ & $8 \%$ \\
\hline 3 & Trainbfg & $92 \%$ & $7 \%$ & $8 \%$ & $92 \%$ & $8 \%$ & $8 \%$ & $92 \%$ & $6 \%$ & $6 \%$ \\
\hline 4 & Traincgb & $92 \%$ & $5 \%$ & $5 \%$ & $92 \%$ & $4 \%$ & $4 \%$ & $92 \%$ & $7 \%$ & $7 \%$ \\
\hline 5 & Trancgf & $92 \%$ & $6 \%$ & $6 \%$ & $92 \%$ & $5 \%$ & $5 \%$ & $92 \%$ & $7 \%$ & $7 \%$ \\
\hline 6 & Traincgp & $92 \%$ & $6 \%$ & $6 \%$ & $92 \%$ & $6 \%$ & $7 \%$ & $93 \%$ & $10 \%$ & $9 \%$ \\
\hline 7 & Traingd & $92 \%$ & $4 \%$ & $4 \%$ & $92 \%$ & $5 \%$ & $5 \%$ & $92 \%$ & $6 \%$ & $6 \%$ \\
\hline 8 & Traingda & $92 \%$ & $7 \%$ & $6 \%$ & $92 \%$ & $6 \%$ & $6 \%$ & $92 \%$ & $5 \%$ & $5 \%$ \\
\hline 9 & Traingdm & $92 \%$ & $4 \%$ & $5 \%$ & $92 \%$ & $5 \%$ & $5 \%$ & $92 \%$ & $5 \%$ & $5 \%$ \\
\hline 10 & Traingdx & $92 \%$ & $6 \%$ & $5 \%$ & $93 \%$ & $9 \%$ & $8 \%$ & $92 \%$ & $8 \%$ & $8 \%$ \\
\hline 11 & Trainoss & $92 \%$ & $7 \%$ & $7 \%$ & $92 \%$ & $7 \%$ & $7 \%$ & $93 \%$ & $7 \%$ & $7 \%$ \\
\hline 12 & Trainrp & $92 \%$ & $7 \%$ & $7 \%$ & $92 \%$ & $5 \%$ & $6 \%$ & $92 \%$ & $8 \%$ & $8 \%$ \\
\hline 13 & Trainscg & $93 \%$ & $10 \%$ & $10 \%$ & $92 \%$ & $3 \%$ & $3 \%$ & $92 \%$ & $7 \%$ & $7 \%$ \\
\hline 14 & Trainb & $95 \%$ & $15 \%$ & $5 \%$ & $92 \%$ & $5 \%$ & $5 \%$ & $92 \%$ & $6 \%$ & $7 \%$ \\
\hline 15 & Trainc & $92 \%$ & $9 \%$ & $9 \%$ & $93 \%$ & $9 \%$ & $8 \%$ & $93 \%$ & $10 \%$ & $10 \%$ \\
\hline 16 & Trainr & $92 \%$ & $7 \%$ & $6 \%$ & $93 \%$ & $7 \%$ & $6 \%$ & $92 \%$ & $8 \%$ & $7 \%$ \\
\hline 17 & Trains & $93 \%$ & $8 \%$ & $5 \%$ & $92 \%$ & $6 \%$ & $6 \%$ & $92 \%$ & $5 \%$ & $5 \%$ \\
\hline RATA-RATA & $92,29 \%$ & $7,24 \%$ & $6,41 \%$ & $92,18 \%$ & $11,47 \%$ & $6,18 \%$ & $92,29 \%$ & $7,29 \%$ & $7,18 \%$ \\
\hline
\end{tabular}

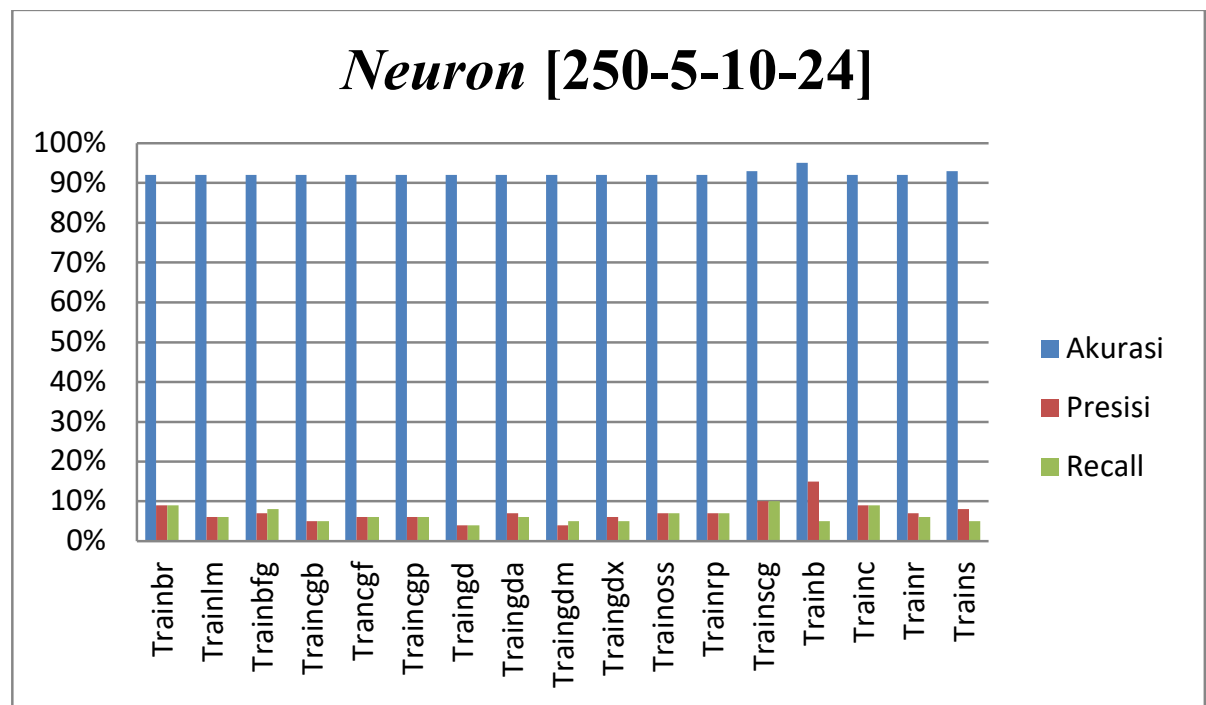

Gambar 3 Grafik Perbandingan 17 function training untuk arsitektur [250-5-10-24]

Berdasarkan Gambar 3 pada 17 function training untuk arsitektur neuron [250-5-10-24] rata-rata nilai akurasi yang dihasilkan diatas $90 \%$, sedangkan untuk presisi sangat kecil dengan nilai kurang dari $20 \%$ dan untuk recall bernilai kurang dari $10 \%$. 
Vol. 1, No. 1, Oktober 2020, Hal. 1 - 11

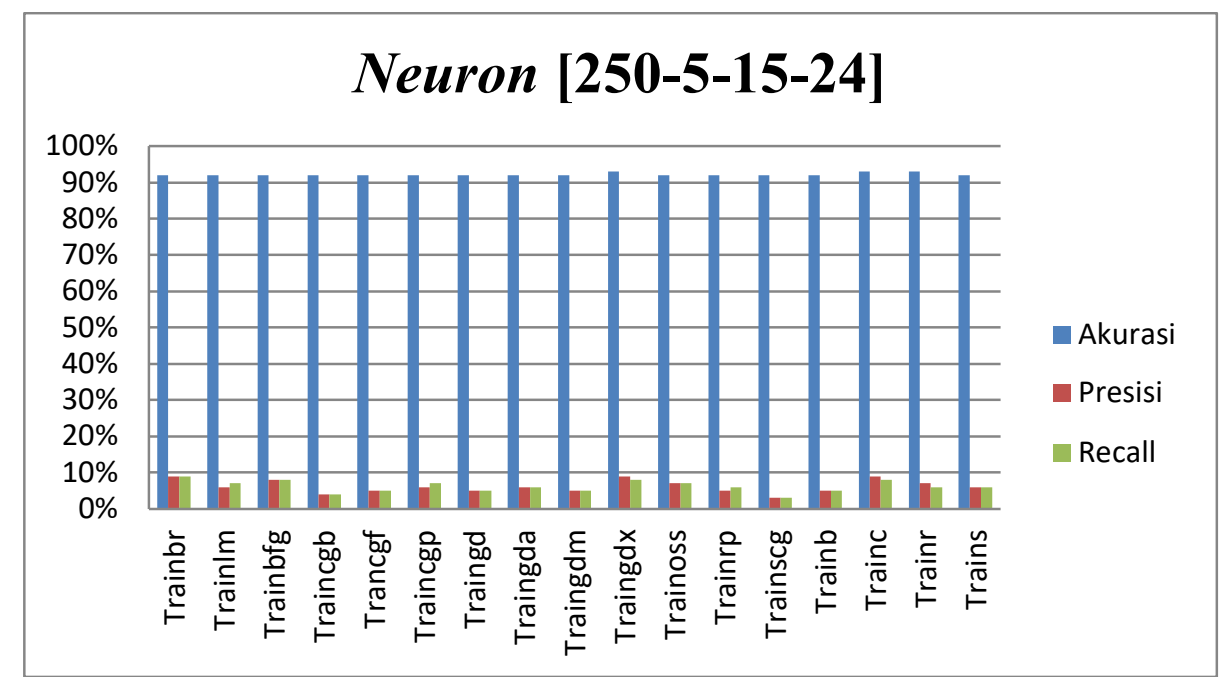

Gambar 4 Grafik Perbandingan 17 function training untuk arsitektur [250-5-15-24]

Berdasarkan Gambar 4 pada 17 function training untuk arsitektur neuron [250-5-10-24] rata-rata nilai akurasi yang dihasilkan diatas $90 \%$, sedangkan untuk presisi dan recall sangat kecil dengan nilai kurang dari $10 \%$.

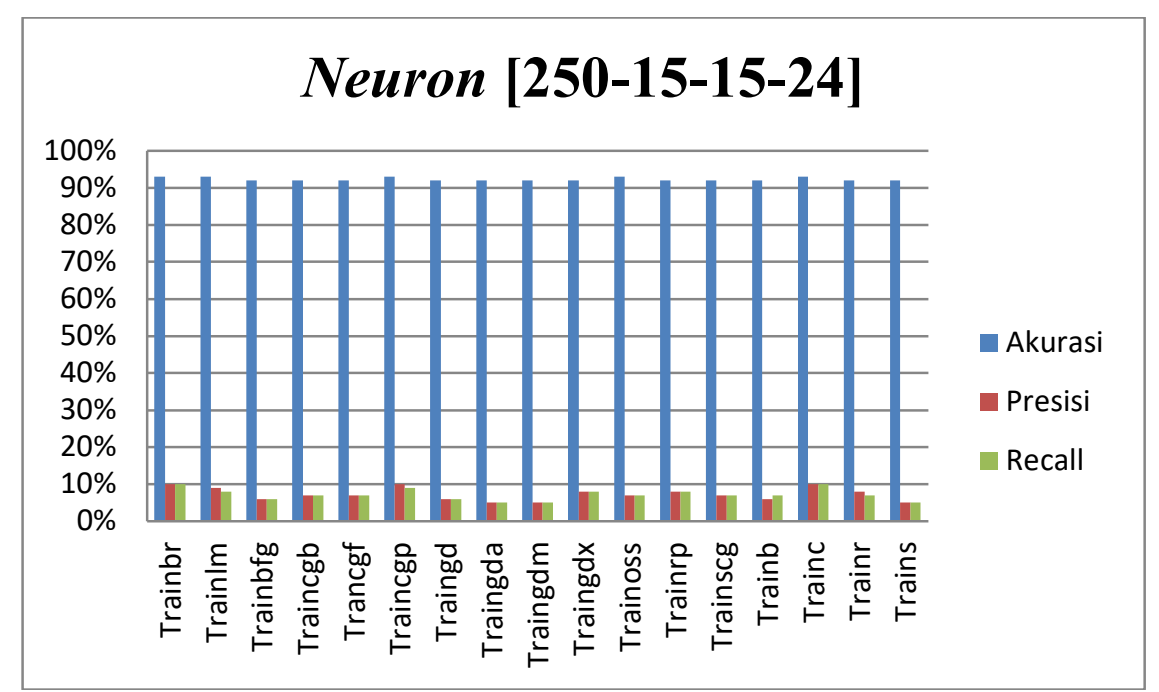

Gambar 5 Grafik Perbandingan 17 function training untuk arsitektur [250-15-15-24]

Berdasarkan Gambar 5 pada 17 function training untuk arsitektur neuron [250-5-10-24] rata-rata nilai akurasi yang dihasilkan diatas $90 \%$, sedangkan untuk presisi dan recall sangat kecil dengan nilai kurang dari $25 \%$.

\section{KESIMPULAN}

Berdasarkan hasil penelitian implementasi JST untuk klasifikasi ASL berdasarkan fitur SIFT, dapat disimpulkan bahwa dalam penggunaan JST pada arsitektur neuron [250-15-15-24] didapat nilai overall accuracy terbaik pada ASL sebesar 92,29\%, untuk nilai overall precision terbaik didapatkan pada arsitektur neuron [250-5-15-24] sebesar 11,47\%, untuk nilai overall recall terbaik didapatkan pada arsitektur neuron [250-15-15-24] sebesar 7,18\%. Penggunaan

Alviando, at., al (Klasifikasi American Sign Language Menggunakan Fitur Scale Invariant Feature Transform Dan Jaringan Saraf Tiruan) 
fitur SIFT dan JST sebagai klasifikasi pada citra ASL dianggap kurang baik karena untuk nilai overall recall yang dihasilkan sangat kecil yang berarti data yang diklasifikasikan dengan benar sesuai jenisnya hanya sedikit.

\section{SARAN}

Berdasarkan kesimpulan yang telah dijelaskan, terdapat saran yang dapat digunakan untuk membantu mengembangkan penelitian selanjutnya agar mendapatkan hasil yang lebih baik dengan melakukan eksperimen pada beberapa jenis resolusi citra yang berbeda dari yang telah dilakukan untuk kemungkinan mendapatkan hasil akurasi pengenalan yang baik, menggunakan metode ekstraksi fitur selain SIFT pada citra ASL dan menggunakan metode selain JST sebagai klasifikasi citra ASL

\section{DAFTAR PUSTAKA}

[1] Ridwang, R. (2017). Pengenalan Bahasa Isyarat Indonesia (SIBI) Menggunakan Leap Motion Controller dan Algoritma Data Mining Naïve Bayes. Jurnal Insypro (Information System and Processing), 2(2). https://doi.org/10.24252/insypro.v2i2.4070.

[2] Hunt, T., Carper, J., Lasley, T., Raisch, C., \& Drasgow, E. (2013). American Sign Language. Encyclopedia of Educational Reform and Dissent. https://doi.org/10.4135/9781412957403.n31

[3] Fareza, I., Busdin, R., Al Rivan, M. E., \& Irsyad, H. (2018). Pengenalan Alfabet Bahasa Isyarat Amerika Menggunakan Edge Oriented Histogram dan Image Matching. Jurnal Teknik Informatika Dan Sistem Informasi, 4(1), 82-92. https://doi.org/10.28932/jutisi.v4i1.747

[4] Al Rivan, M. E., Irsyad, H., Kevin, K., \& Narta, A. T. (2020). Pengenalan Alfabet American Sign Language Menggunakan K-Nearest Neighbors Dengan Ekstraksi Fitur Histogram Of Oriented Gradients. Jurnal Teknik Informatika Dan Sistem Informasi, 5(3), 328-339. https://doi.org/10.28932/jutisi.v5i3.1936

[5] Al Rivan, M. E., \& Juangkara, T. (2019). Identifikasi Potensi Glaukoma dan Diabetes Retinopati Melalui Citra Fundus Menggunakan Jaringan Syaraf Tiruan. JATISI (Jurnal Teknik Informatika Dan Sistem Informasi), 6(1), 43-48. https://doi.org/10.35957/jatisi.v6i1.158

[6] Al Rivan, M. E., Rachmat, N., \& Ayustin, M. R. (2020). Klasifikasi Jenis KacangKacangan Berdasarkan Tekstur Menggunakan Jaringan Syaraf Tiruan. Vol 6 No 1. https://doi.org/doi.org/10.35143/jkt.v6i1.3546

[7] Mahfudi, I., Sarosa, M., Andrie Asmara, R., \& Azrino Gustalika, M. (2018). Indonesian Sign Language Number Recognition using SIFT Algorithm. IOP Conference Series: Materials Science and Engineering, 336(1), 0-8. https://doi.org/10.1088/1757899X/336/1/012010

[8] Patil, S. B., \& Talwekar, R. H. (2017). Implementation of indian sign language recognition system using scale invarient feature transform (sift). International Journal of Computer Science and Information Security (IJCSIS), 15(2), 493-507. https://s3.amazonaws.com/academia.edu.documents/52348530/52_Paper_31011787_IJCS

Alviando, at., al (Klasifikasi American Sign Language Menggunakan Fitur Scale Invariant Feature Transform Dan Jaringan Saraf Tiruan) 
Vol. 1, No. 1, Oktober 2020, Hal. 1 - 11

IS_Camera_Ready_493-507.pdf?response-content-disposition=inline $\% 3 \mathrm{~B}$

filename\%3DIMPLEMENTATION_OF_INDIAN_SIGN_LANGUAGE_R.pdf\&X-AmzAlgorithm=AWS4-HMAC-SHA256\&X-Amz-Credential=AKI

[9] Mahmud, H., Hasan, M. K., Al-Tariq, A., \& Mottalib, M. A. (2016). Hand Gesture Recognition Using SIFT Features on Depth Image. The Ninth International Conference on Advances in Computer-Human Interactions Hand, April, 359-365.

[10] Sreejith, S. (2018). GitHub - mon95/Sign-Langauge-and-Static-recognition. Diakses pada Tanggal 28 Juli 2020. Retrieved from github.com website: https:/github.com/mon95/SignLanguage-and-Static-gesture-recognition-using-sklearn 